Удк 303.4:631.85

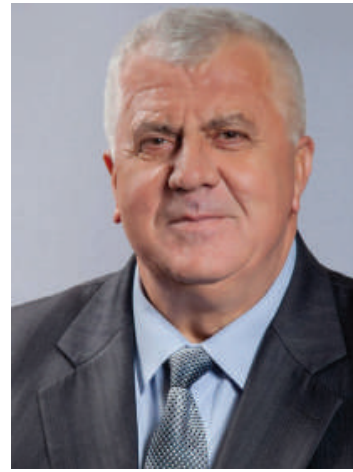

\title{
B.I. Невлад,
}

кандидат сільськогосподарських наук,

Уманський національний університет садівництва

E-mail:unus_agrochem@ukr.net

DOI: $10.31395 / 2310-0478-2021-2-13-19$

Г.М. Господаренко, доктор сільськогосподарських наук, Уманський національний університет садівництва м. Умань, Україна E-mail: Hospodarenko@gmail.com

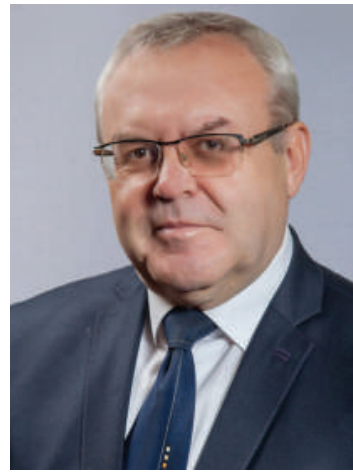

A.T. Мартинюк, кандидат сільськогосподарських наук, Уманський національний університет садівництва

м. Умань, Україна E-mail:martunyk_andriy_t@ukr.net

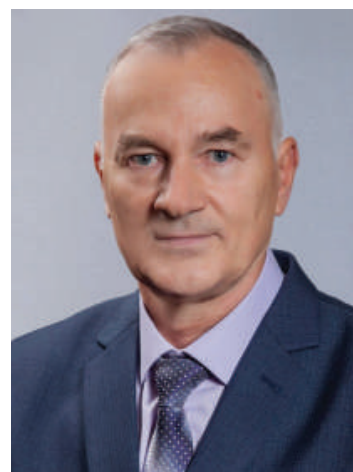

\section{ОБҐРУНТУВАННЯ МЕЖІ ДОЦІЛЬНОСТI ЗАСТОСУВАННЯ ФОСФОРНИХ ДОБРИВ}

Анотація. Розглянуто питання окупності фосфорних добрив. Показано, що раніше виконані розробки нормативів окупності фосфорних добрив не завжди підтверджуються в сучасних умовах диспаритету цін. Встановлено, що за ціни на суперфосфат гранульований 11000 грн/т і витрати на його застосування в оптимальних дозах під польові культури на тлі збалансованого азотно-калійного живлення вартість приросту врожаю складає 2153-25194 грн/га. Окупність(збитковість) застосування 1 кг д. р. фосфорних добрив змінюється в широкому діапазоні - від -40,0 до 346,2 грн залежно від культури. Межа збитковості ціни за одиницю діючої речовини фосфорних добрив за оптимальної дози внесення залежить від культури і знаходиться в діапазоні 25-417 грн/кг. За нинішнього диспаритету цін на продукцію рослинництва і суперфосфат гранульований, його застосування $\epsilon$ збитковим під жито озиме, сорго зернове $i$ буряк цукровий (за внесення на тлі 40 т/га гною). Це можна пояснити середньою забезпеченістю рослин фосфором на чорноземі опідзоленому, біологічними особливостями культур і технологіями їх вирощуваннями.

Ключові слова: фосфорні добрива, сільськогосподарські культури, окупність добрив, межа збитковості, межа підвищення ціни.

\section{H.M. Hospodarenko,}

Doctor of Agricultural Sciences, Professor of the Department of Agricultural Chemistry and Soil Science, Uman National Horticulture University (Uman), Ukraine

A.T. Martyniuk,

PhD of Agricultural Sciences, Associate Professor of the Department of Agricultural Chemistry and Soil Science, Uman National Horticulture University (Uman), Ukraine

V.I. Nevlad

PhD of Agricultural Sciences, Associate Professor of the Department of Agricultural Chemistry and Soil Science, Uman National Horticulture University (Uman), Ukraine

\section{JUSTIFICATION OF THE LIMIT OF EXPEDIENCY OF USING PHOSPHOROUS FERTILIZERS}

Abstract. The issues of recoupment of phosphorous fertilizers, that are the most disputable in agronomy because of the determined necessity in fertilizers and their economic efficiency of usage, were studied. It has been presented, that recoupment of fertilizers is a complex and not constant value for different crops. It has been established that at a price for grainy superphosphate of $11000 \mathrm{UAH} / t$ and the cost of its use in optimal doses for field crops on the basis of a balanced nitrogen-phosphorus nutrition, the cost of an increase in yield is 2153-25194 UAH/ ha. Payback (unprofitableness) of 1 $\mathrm{kg}$. phosphorous fertilizers varies in a wide range - from - 40.0 UAH to 346,2 UAH, depending on the crop. The limit of the unprofitable price per unit of the active substance of phosphorous fertilizers at the optimal dose of application depends on the crop and is in the range of 25-417 UAH/kg. With the current disparity in prices for crop products and grainy superphosphate, its use is unprofitable for winter rye, spring barley, grain sorghum and sugar beet (when applied against a background of $40 \mathrm{t} / \mathrm{ha}$ of manure). It is due to the availability of graded chernozem with mobile potassium compounds, biological characteristics of crops and technologies for their cultivation.

Key words: phosphorous fertilizers, agricultural crops, fertilizer payback, loss threshold, price increase limit. 
Постановка проблеми. Серед заходів реалізації концепції досягнення нейтрального рівня деградації ґрунтів в Україні важливе значення належить застосуванню агротехнологій, що забезпечують відновлення їх родючості та запобігання забруднення [12]. Характерною ознакою родючості ґрунтів $\epsilon$ їх фосфатний рівень, а його підвищення - одним з основних показників окультурення. Для уточнення доз застосування фосфорних добрив у польовій сівозміні та оптимізації фосфорного живлення окремих сільськогосподарських культур, необхідно встановити, як змінюються агрохімічні властивості ґрунту під дією різних доз фосфорних добрив, кількісне засвоєння і витрати фосфору на формування врожаю, його участь у формуванні врожаю та вплив на ефективність систем удобрення. В Україні окупність мінеральних добрив, у тому числі фосфорних, урожаями значно менша, ніж у країнах Європейського Союзу [10]. Вона також різна залежно від ґрунтово-кліматичних і погодних умов. Ефективність фосфорних добрив також істотно залежить від їх форм, способів і строків внесення [6] і в першу чергу від доз їх внесення. Оптимальна доза добрив повинна враховувати біологічні особливості культур і запланований рівень урожайності, погодні умови і родючість ґрунту, рівень агротехнології, розміщення культур у сівозміні та насичення ї̈̈ добривами, форми добрив, строки і способи їх внесення та інші чинники. Тому визначення доз добрив $\epsilon$ одним зі складних питань сучасної агрономічної науки і практики $[3,31]$. Крім цього встановлено, що за систематичного застосування добрив, одержання високої врожайності сільськогосподарських культур можливе за внесення значно менших доз, що пояснюється післядією добрив, внесених під попередні культури сівозміни.

Нині добрива $€$ одним із найсуттєвіших чинників підвищення продуктивності сільськогосподарських культур. При цьому не викликає сумніву і те, що за економічно обґрунтованої дози добрив проблема полягає у формуванні не якомога більшого врожаю, а такого, який забезпечує найліпші економічні показники [29]. Зазвичай вважається, що найефективнішою системою удобрення $\epsilon$ та, що забезпечує максимальний приріст урожаю сільськогосподарських культур. 3 економічного погляду це не завжди є доцільним у тривалій перспективі, тому що ціни на мінеральні добрива ростуть більшими темпами, ніж на продукцію рослинництва.

Окупність добрив розраховується за низкою нормативних документів, де наведено нормативи витрати добрив і прибавок урожаю від застосування зростаючих їх доз $[19,22]$, а також нормативів витрат добрив для одержання приросту врожаю [8, 20, 24]. Диспаритет цін між вартістю мінеральних добрив і вартістю сільськогосподарської продукції в Україні не завжди дозволяє одержати економічний ефект від застосування мінеральних добрив $[5,11]$. Нині для придбання 1 кг д. р. фосфорних добрив необхідно продати 8,5 кг зерна пшениці озимої, крім того, їх ще потрібно доставити у господарство, внести, понести витрати на збирання і доробку додатково одержаного урожаю завдяки їх застосуванню. Отже, раціональне використання фосфорних добрив у зв'язку з обмеженістю їх застосування перетворилось у найважливішу проблему землеробства, тому питання обґрунтування доцільності й ефективності застосування фосфорних добрив з метою зниження, за необхідності, їх доз нині $€$ актуальним.

Аналіз останніх досліджень і публікацій. Дискусії з методології розрахунку та величини нормативів окупності фосфорних добрив, не дивлячись на тривалу історію питання, серед учених і практиків виробництва продовжуються. До основних його складових можна віднести такі міфи:

чорноземні ґрунти містять значні запаси фосфору, тому рослини можуть його засвоювати в необхідній кількості за оптимального живлення азотом;

окупність фосфору добрив в Україні значно менша, ніж у країнах Західної Європи;

застосування фосфорних добрив у сучасних економічних умовах низькорентабельне, тому їх застосу- вання недоцільне;

- окупність фосфорних добрив досить низька, тому їх застосовувати доцільно лише на бідних ґрунтах і в малих дозах.

Причиною цього $є$ різні методичні підходи до проведення розрахунків. Більшість помилок пов'язані 3 віднесенням застосування добрив до поточних витрат виробництва, хоч фосфорні добрива мають значну післядію і по суті $\epsilon$ капітальними вкладеннями. У зв'язку з поліпшення технологій вирощування культур раніше виконані розробки «нормативів окупності» виявилися значно заниженими. Окупність добрив $є$ величиною комплексною і не сталою в часі. Агрономічна ефективність від внесення добрив потребує обов'язкового врахування післядії. Термін «норматив окупності» не відповідає сучасним соціально-економічним умовам. Тому ліпше вживати загальноприйнятий у світовій практиці термін «агрономічна ефективність добрив» $[17,23]$.

У зв'язку з переходом сільського господарства на ринкові відносини вирішити нагальні проблеми на принципах затратної економіки неможливо. Розрахунки показують, що майже половина всіх витрат у технології вирощування культур припадає на добрива [26, 27]. Для зниження енерговитрат на застосування фосфорних добрив необхідно планувати їх застосування не для одержання максимально можливого врожаю, а на раціональний його рівень 3 максимальною окупністю одиниці діючої речовини і за помірних темпів поповнення ґрунтових запасів рухомих сполук фосфору до нижньої оптимальної межі [4]. Особливість взаємодії між рослиною, добривом, ґрунтом і погодою зумовлює складність встановлення потреби культур у фосфорі та $\epsilon$ вузьким місцем у системі застосування фосфорних добрив [21].

Не дивлячись на те, що ґрунти України мають значні запаси валового фосфору, баланс його для чорноземів має особливе значення $[4,21]$. Колообіг фосфору простіший, ніж азоту, тобто його складовими зазвичай $є$ лише ґрунт і рослини. Вважається [13], що для підвищення родючості ґрунту необхідно мати інтенсивність балансу фосфору 180-200\%, що забезпечується середньорічним внесенням 60-80 кг/га $\mathrm{P}_{2} \mathrm{O}_{5}$. Проте, існує й думка [30], що з підвищенням вмісту фосфору в чорноземних ґрунтах дози фосфорних добрив можна зменшити, оскільки високий рівень фосфатів знижує якість рослинницької продукції і доступність рослинам низки мікроелементів.

У тривалому досліді на дерново-підзолистому супіщаному ґрунті встановлено, що поліпшення фосфатного стану ґрунту не пропорційне дозам фосфорних добрив. Подібно цій закономірності формується і продуктивність сівозміни [7]. Для оптимізації мінерального живлення у польових сівозмінах і підвищення родючості сірого лісового ґрунту Правобережного Лісостепу рекомендується максимально залучати нетоварну частину врожаю та вносити невисокі дози фосфорних добрив [3].

На чорноземі типовому Лівобережного Лісостепу в польових сівозмінах на 10-15 років можуть впроваджуватися системи удобрення, які не покривають винесення фосфору врожаями [9]

у Білорусі система застосування мінеральних добрив передбачає повернення елементів живлення, що компенсує винесення їх з вилученим урожаєм i забезпечує поступове підвищення вмісту рухомих сполук фосфору і калію до 200-300 мг/кг ґрунту. При цьому внесення фосфорних добрив повинно на $100 \%$ компенсувати вилучення фосфору запланованою врожайністю сільськогосподарських культур, на ґрунтах з вмістом рухомих сполук фосфору нижче оптимального значення 120 , а на ґрунтах з їх вмістом вище оптимуму - на 50 \% вилучених з урожаями [15].

У зв'язку з тим, що чорноземи мають значні запаси фосфору, на ділянках без внесення добрив проходить його біопереміщення з нижніх шарів ґрунту [14]. Це дає можливість допустити незначний тимчасовий від'ємний баланс фосфору в ґрунті.

Отже, з огляду наукових джерел, рекомендовані в довідковій літературі дози фосфорних добрив зазвичай 
не враховують залишкового вмісту в ґрунті рухомих сполук фосфору і були розраховані за розвинутого зазвичай у кожному господарстві тваринництва, що зумовлювало видалення нетоварної частини урожаю з поля. Тому в умовах енергетичної кризи важливо встановити сучасний рівень окупності фосфорних добрив.

Врахування економічних чинників внесення фосфорних добрив - важлива складова у вирішенні питання доцільності застосування фосфору на певному полі під конкретну культуру. Зрозуміло, що встановлення економічної доцільності внесення фосфорних добрив тільки мала частина всього комплексу розрахунків рівня ефективності роботи певного господарства, яку в низці випадків можна і не враховувати. Але у зв'язку з диспаритетом цін на добрива і продукцію рослинництва, як окремий фрагмент оцінювання всієї діяльності господарства чи галузі рослинництва, важливо визначити окремо пряму економічну вигоду від внесення певного виду чи форми мінеральних добрива.

На жаль, єдиних загальноприйнятих критеріїв оцінювання економічної ефективності застосування добрив в цілому і, тим більше, окремих їх видів і форм не розроблено [28]. Частково це пов'язано зі значною строкатістю ґрунтово-кліматичних умов вирощування сільськогосподарських культур і їх реакцією на окремі елементи живлення [5, 18].

Офіційна методика розрахунків економічної ефективності в рамках системи державного планування в основному викладена в працях учених ННЦ «Інститут ґрунтознавства та агрохімії ім. О. Н. Соколовського», Інституту аграрної економіки й інших установ. В основу розрахунків покладено нормативна база частки участі добрив у формуванні приросту врожаю на основі даних географічної мережі польових дослідів і визначення фактичної окупності 1 кг їх діючих речовин приростом урожаю в зернових або кормових одиницях з досить складною системою визначення витрат на застосування добрив. Також, з урахуванням частки участі добрив у формуванні приросту врожаю, були проведені розрахунки з агрономічного обґрунтування застосування фосфорних добрив [3]. Отримані дані дозволяють об'єктивно оцінити потребу в фосфорних добривах.

Наведені в літературі методики розрахунку економічної ефективності застосування добрив зазвичай стосувалися великих регіонів. Нині, у зв'язку з дороговартістю фосфорних добрив, виникла необхідність розрахунку ефективності їх застосування в певному господарстві та під конкретну культуру.

Обґрунтуванню рівня удобрення та раціонального застосування фосфорних добрив присвятили свої дослідження низка вчених, зокрема К. П. Афендулов, Л. М. Державін, Т. І. Іванова, Л. Кевай, Д. А. Кореньков, Т. Н. Кулаковська, О. В. Лазурський, В. Л. Локо, М. В. Лісовий, Ф. Е. Мосіюк, Б. С. Носко, А. Ольм, А. В. Піхо, В. П. Фефєлов, О. В. Ходаківська та ін. [16]. При цьому було використано критерії економічного оцінювання застосування добрив. Їх основу складає визначення меж економічної доцільності застосування добрив: мінімально необхідної прибавки урожаю та межі підвищення ціни на добриво.

Зростання витрат на застосування добрив і виробництво сільськогосподарської продукції, диспаритет цін на них викликають необхідність визначення меж збитковості застосування доз мінеральних добрив під певну культуру, в господарствах і певних регіонах країни.

По-перше, як зазначалося вище, необхідно встановити мінімально необхідну прибавку врожаю від добрив, щоб виправдати витрати на їх застосування. По-друге, важливо знати межу підвищення цін на добриво за одержуваного приросту врожаю, що показує доцільність його застосування. Це завдання може бути вирішено за пропонованою нижче методикою.

Правильніше та повніше оцінювання економічної ефективності застосування добрив встановлюється на основі системи таких основних показників: вихід продукції з одиниці площі, продуктивність праці, собівартість продукції, чистий прибуток, рентабельність виробництва продукції, окупність додаткових витрат на добрива, вартістю прибавки урожаю. Ці показники характеризують вплив добрив на кінцеві результати виробництва продукції за інших рівних умов. Вони взаємопов'язані і взаємозумовлені. Чим більше вихід продукції і вища продуктивність праці, нижча собівартість, більший чистий дохід і вища рентабельність виробництва продукції, тим вища економічна ефективність застосування добрив. Узагальнюючими з цих показників $\epsilon$ вихід продукції і чистий дохід, що одержувані завдяки застосуванню добрив. За ними зазвичай і робляться остаточні висновки.

Мета статті - обґрунтувати межі окупності фосфорних добрив під різні сільськогосподарські культури з врахуванням їх післядії, уточнити поняття нормативу окупності добрив, порогу збитковості та максимальної ціни на них.

Методика досліджень. На практиці зазвичай використовується більш простий спосіб оцінювання ефективності застосування добрив на основі порівняння двох показників: вартості прибавки урожаю від них (ПУ) і додаткових витрат на застосування добрив (ДВ). Різниця між вартістю прибавки врожаю і додатковими витратами дає чистий дохід (ЧД), що одержаний від застосування добрив: ЧД = ПУ - ДВ. Чим більший чистий дохід і збільшення врожаю з одиниці посівної площі, тим вища економічна ефективність застосування добрив. Відношення вартості прибавки урожаю (ПУ) до додаткових витрат (ДВ) показує їх окупність (О): О = ПУ : ДВ. Цей показник показує, скільки на кожну гривню додаткових витрат на застосування добрив одержано додаткової продукції у грошовому еквіваленті.

На основі порівняння показників Пу і ДВ визначаються і межі економічної ефективності застосування добрив: ПУ > ДВ (загальний вираз завдання).

Приріст урожаю від добрив у натурі взято за даними короткотермінових і багаторічного польових дослідів з добривами, проведених на чорноземі опідзоленому важкосуглинковому дослідного поля Уманського національного університету садівництва [25], що розміщене в Правобережному Лісостепу України з географічними координатами за Гринвічем 48 46' північної широти і $30^{\circ} 1^{\prime} 4^{\prime}$ східної довготи. Вартість прибавки врожаю від застосування фосфорних добрив визначали за середніми фактичними цінами реалізації продукції, що склалися на ринку по різних каналах збуту у VI кварталі 2021 р. При цьому ціна на суперфосфат гранульований з вмістом $19 \% \mathrm{P}_{2} \mathrm{O}_{5}$ становила 11000 грн/т.

Додаткові витрати включали: вартість добрив, націнку на доставку їх у господарство, витрати на застосування в господарстві та витрати на збирання прибавки урожаю від добрив. Вартість фосфорного добрива брали за діючими цінами придбання з додаванням націнки на доставку їх у господарство. Витрати на застосування добрив у господарстві та на збирання прибавки врожаю встановлювали розрахунково за прийнятими нормативами.

Рівність Пу = ДВ (нижня межа економічно ефективності застосування добрив, або поріг збитковості) означає, що врожай збільшився, але його вартість порівнюється з додатковими витратами. Тобто чистого доходу немає, а ефективність добрив у цьому випадку виражається лише в прирості врожаю. Зрозуміло, що фермери, а також виробники добрив та їх постачальники, як комерційні організації, зацікавлені не в рівності порівнюваних показників, а в отриманні максимально можливого чистого доходу і, відповідно, прибутку від добрив як реалізованої частини чистого доходу.

Мінімально необхідну прибавку врожаю від добрив визначали за такою формулою:

$X=($ ВД + НД + ВЗ) КД : Ц,

де $X$ - шукана мінімально необхідна прибавка врожаю від добрив, т/га; ВД - вартість добрив, грн/га; НД - націнка за доставку добрив у господарство, грн/га; ВЗ - витрати на застосування добрив у господарстві, грн/ га; КД - коефіцієнт використання фосфору добрив у рік 
внесення; Ц - ціна реалізації 1 т прибавки врожаю, грн; В3 - витрати на збирання 1 т прибавки врожаю від добрив, грн.

Межі підвищення цін на добрива визначали за такою формулою:

$\mathrm{y}=$ ПУ $-[($ НД + ЗД) $\mathrm{K}+\mathrm{BП}]$,

де У - шукана межа підвищення ціни на добриво, грн/га; Пу - вартість прибавки урожайності від добрив, грн/га; НД - націнка за доставку добрива в господарство, грн/га; ЗД - витрати на застосування добрив у господарстві, грн/га; К - коефіцієнт використання поживних речовин з суперфосфату гранульованого в рік внесення - 0,25; ВП - витрати на збирання прибавки врожаю, грн/га.

Результати досліджень. Встановлено, що ефективність фосфорних добрив залежить від сільськогосподарської культури (табл. 1). При цьому вартість приросту врожаю від їх застосування змінюється від 25194 грн/га (кукурудза) до 2153 грн/га (жито озиме).

Ефективність застосування фосфорних добрив під польові культури за збалансованого азотного й калійного живлення

\begin{tabular}{|c|c|c|c|c|c|c|}
\hline Культура & $\begin{array}{l}\text { Доза } \\
\mathrm{P}_{2} \mathrm{O}_{5 \prime} \\
\text { кr/ra }\end{array}$ & $\begin{array}{c}\text { Витрати на } \\
\text { застосування } \\
\text { Фосфорних } \\
\text { добрив, } \\
\text { грн/га }\end{array}$ & $\begin{array}{c}\text { Приріст } \\
\text { урожаю від } \\
\text { фосфорних } \\
\text { добрив, т/га }\end{array}$ & $\begin{array}{c}\text { Вартість при- } \\
\text { росту вро- } \\
\text { жаю, грн/га }\end{array}$ & $\begin{array}{c}\text { Окупність } \\
\text { (збитковість) } \\
1 \text { кг } P_{2} O_{5}, \text { грн }\end{array}$ & $\begin{array}{c}\text { Мінімальна } \\
\text { необхідна при- } \\
\text { бавка врожаю } \\
\text { від фосфорних } \\
\text { добрив, т/га }\end{array}$ \\
\hline Пшениця озима & 60 & 4080 & 1,00 & 6800 & 45,3 & 0,60 \\
\hline Жито озиме & 60 & 3960 & 0,37 & 2153 & $-30,1$ & 0,68 \\
\hline Ячмінь ярий & 70 & 4010 & 0,81 & 6075 & 34,4 & 0,53 \\
\hline Кукурудза & 60 & 4420 & 3,23 & 25194 & 346,2 & 0,57 \\
\hline Сорго зернове & 90 & 6120 & 0,36 & 2520 & $-40,0$ & 0,87 \\
\hline Hyt & 60 & 3950 & 0,40 & 7320 & 56,2 & 0,22 \\
\hline Сочевиця & 30 & 2060 & 0,26 & 7800 & 191,3 & 0,07 \\
\hline Соя & 60 & 4120 & 0,50 & 8250 & 68,8 & 0,25 \\
\hline Льон олійний & 60 & 3890 & 0,28 & 6720 & 47,2 & 0,16 \\
\hline Рижій ярий & 60 & 3980 & 0,16 & 4800 & 13,7 & 0,13 \\
\hline Буряк цукровий* & 120 & 8210 & 4,00 & 7360 & $-7,1$ & 4,46 \\
\hline
\end{tabular}

Примітка: : 1 - дані по пшениці озимій, ячменю ярому, кукурудзі та сої середні за 10 років у стаціонарному досліді [25], по решті культурах - за три роки у короткотермінових дослідах;

2 - *на тлі 40 т/га напівперепрілого гною ВРX.

Збитковим застосування з агрохімічного погляду оптимальних доз фосфорних добрив було під жито озиме, сорго зернове й буряк цукровий, а мінімальна необхідна прибавка врожаю від них відповідно повинна становити 0,68 т/га; 0,87 і 4,46 т/га. Необхідно також зазначити, що низька окупність застосування фосфорних добрив під буряк цукровий пояснюється внесенням великої кількості рухомих сполук фосфору з напівперепрілим гноєм ВРХ. Звідси межа підвищення ціни на фосфорну складову системи удобрення з урахуванням післядії добрива відповідно складе 2025 грн/га, 2324 і 7099 грн/ га, а вартість суперфосфату гранульованого не повинна перевищувати відповідно для цих культур 6460 грн/га, 4940 та 11210 грн/га (табл. 2).

Межі підвищення ціни на фосфорне добриво під польові культури за збалансованого азотного й калійного живлення

\begin{tabular}{|c|c|c|c|c|}
\hline \multirow[b]{2}{*}{ Культура } & \multirow{2}{*}{$\begin{array}{c}\text { Доза } \mathrm{P}_{2} \mathrm{O}_{5} \\
\kappa r / \mathrm{ra}\end{array}$} & \multicolumn{3}{|c|}{ Межа підвищення ціни на фосфорне добриво } \\
\hline & & грн/га & $\Gamma \mathrm{PH} / \mathrm{Kr} \mathrm{P}_{2} \mathrm{O}_{5}$ & $\begin{array}{c}г p н / \tau \\
\text { суперфосфату } \\
\text { гранульованого }\end{array}$ \\
\hline Пшениця озима & 60 & 6660 & 111 & 21090 \\
\hline Жито озиме & 60 & 2025 & 34 & 6460 \\
\hline Ячмінь ярий & 70 & 5935 & 99 & 18810 \\
\hline Кукурудза & 60 & 25039 & 417 & 79230 \\
\hline Сорго зернове & 90 & 2324 & 26 & 4940 \\
\hline Hyт & 60 & 7192 & 120 & 22800 \\
\hline Сочевиця & 30 & 758 & 25 & 4750 \\
\hline Соя & 60 & 8119 & 135 & 25650 \\
\hline
\end{tabular}




\begin{tabular}{|l|c|c|c|c|}
\hline Льон олійний & 60 & 6592 & 112 & 21280 \\
\hline Рижій ярий & 60 & 4677 & 78 & 14820 \\
\hline Буряк цукровий* & 120 & 7099 & 59 & 11210 \\
\hline
\end{tabular}

Примітка: : 1 - дані по пшениці озимій, ячменю ярому, кукурудзі та сої середні за 10 років у стаціонарному досліді [25], по решті культурах - за три роки у короткотермінових дослідах;

2 - *на тлі 40 т/га напівперепрілого гною ВРX.

За доз внесення фосфорних добрив, що вивчалися в досліді, агрономічно виправданим буде їх застосування після підвищення ціни на суперфосфат гранульований, грн: до 11210 (під буряк цукровий) і навіть до 79230 (під кукурудзу). За нинішньої ціни на суперфосфат гранульований (11000 грн/т) застосування його під жито озиме, сорго зернове і буряк цукровий (на тлі 40 т/га гною) $\epsilon$ збитковим. Це можна в певній мірі пояснити тим, що ці культури здатні засвоювати фосфор з важкорозчинних сполук ґрунту, а буряк цукровий ефективно використовує дію гною. Крім того, всі польові досліди були проведені на чорноземі опідзоленому важкосуглинковому, який характеризується середнім рівнем забезпеченості рослин фосфором.

Наведені розрахунки показують, наскільки важливо правильно встановити усі вихідні дані для вирішення питання в конкретних умовах господарювання. Вони також наочно свідчать про ефективність фосфорних добрив за обґрунтованого їх застосування з урахуванням ґрунтово-кліматичних і господарських умов. На практиці збільшення врожайності сільськогосподарських культур від фосфорних добрив з урахуванням оптимальних доз, форм, строків і способів внесення може значно перевищувати середні прирости, взяті для розрахунків.

У наведених прикладах у розрахунках використані умовні показники і ціни, що склались на певний період. Для кожної зони, типу ґрунту, відстані перевезення добрив, культури, а також приросту врожаю, результати можуть бути різними. При цьому необхідно враховувати, що в наведені розрахунки закладалося тільки збільшення врожаю. Однак, як видно з результатів проведених досліджень $[1,21,31]$, фосфорні добрива сприяють поліпшенню якості продукції, її лежкості й транспортуванню, підвищують стійкість рослин в екстремальних умовах. у виробничих умовах така дія фосфору добрив іноді може бути навіть важливішою, ніж просто прибавка врожаю основної продукції.

Не можна також забувати, що основна мета застосування фосфорних добрив - не межі їх економічної ефективності, а отримання максимально можливої прибавки врожаю та чистого доходу від них у розрахунку на одиницю посівної площі та відновлення й поступове підвищення вмісту в ґрунті рухомих сполук фосфору до оптимального рівня. Проведення ж таких розрахунків повинно застерігати і виробників, і споживачів добрив від порушення цієї основної вимоги.

Висновки. 1. За ціни на суперфосфат гранульований $з$ вмістом $19 \% \mathrm{P}_{2} \mathrm{O}_{5} 11000 \mathrm{rрн} / \mathrm{T}$ і витрат на його застосування в оптимальних дозах на тлі збалансованого азотного й калійного живлення вартість приросту врожаю становить 2153-25194 грн/га залежно від сільськогосподарської культури.

2. Окупність (збитковість) 1 кг д. р. фосфорних добрив змінюється в широкому діапазоні - від $-40,0$ до 346,2 грн залежно від сільськогосподарської культури.

3. Межа збитковості ціни за одиницю діючої речовини фосфорних добрив за оптимальної дози внесення залежить від культури і знаходиться в діапазоні 25-417 грн/кг. За нинішнього диспаритету цін на продукцію рослинництва і суперфосфат гранульований (11000 грн/т), його застосування $є$ збитковим під жито озиме, сорго зернове і буряк цукровий (за внесення на тлі 40 т/га гною), що пояснюється середньою забезпеченістю рослин фосфором на чорноземі опідзоленому, біологічними особливостями культур і технологіями їх вирощування.

\section{Література.}

1. Волкогон В. В., Бердніков О. М., Лопушняк В. I. Екологічні аспекти системи удобрення сільськогосподарських культур; за ред. В. В. Волкогона. Київ: Аграрна наука, 2019. 264 с.

2. Господаренко Г. М. Практикум з агрохімії. Київ : ТОВ «СІК ГРУП УКРАЇНА», 2020. 148 с.

3. Господаренко Г. М., Мартинюк А. Т., Бойко В. П. Баланс фосфору в ґрунті та ефективність фосфордефіцитної системи удобрення. Вісник Уманського НУС. Умань, 2021. № 1. С. 21-26.

4. Господаренко Г. М., Черно О. Д., Сухомуд О. Г. До питання оптимального вмісту рухомих форм фосфору і калію в чорноземі опідзоленому для культур польово сівозміни. Фактори родючості ґрунту та їх ефективність. Умань, 1998. С. 66-71.

5. Господаренко С. Г. Економічна ефективність мінеральної системи удобрення в польовій сівозміні. Матеріали конф. молодих учених. Умань, 2004. С. 39-40.

6. Господаренко Г. М. Розробка та обґрунтування інтегрованої системи удобрення в польовій сівозміні на чорноземі опідзоленому Правобережного Лісостепу України: автореф. дис. ... д-ра с.-г. наук : 06.01 .04 агрохімія. Київ, 2001. 40 с.

7. Дегодюк Е. Г., Дерев'янко Р. Г., Лісовий М. В. Методи розрахунку норм добрив на запланований урожай. Довідник по удобренню сільськогосподарських культур. Київ : Урожай, 1987. С. 177-187.

8. Добрива: довідник / за ред. М.М.Мірошниченка. Харків : ХНАУ ім. В. В. Докучаєва, 2011. 224 с.

9. Доценко О. В. Вплив тривалого застосування добрив на агрохімічні показники чорнозему типового та ефективність ресурсноощадних систем удобрення: автореф. дис. ... канд. с.-г. наук: 06.01.04 - агрохімія. Харків. 2013. 23 c.

10. Еволюція методологічних і методичних аспектів оцінки земель в Україні (наукова доповідь) / М. М. Федоров, В. Я. Месель-Веселяк, С. А.Балюк та ін. [за ред. М. М. Федорова]. Київ: ННЦ «IAЕ», 2017. 84 с.

11. Калінчик М. В. Ільчук М. М., Калінчик М. Б. Економічне обґрунтування норм внесення мінеральних добрив залежно від ціни на ресурси та продукцію. Київ : Нічлава, 2006. 43 с.

12. Концепція досягнення нейтрального рівня деградації земель (ґрунтів) України . за наук. ред. С. А Балюка, В. В. Медведева, М. М. Мірошниченка. Харків: ФОП Бровін О. В., 2018. 32 с.

13. Крамарьов С. М., Крамарьов О. С. Зміна вмісту рухомих форм фосфору в чорноземах звичайних на ріллі в порівнянні $з$ цілиною та фінансовий механізм його підвищення. Агрохімія і ґрунтознавство (спецвипуск). 2018. Кн. 2. С. 173-174.

14. Крупеников И. А. Черноземы. Возникновения, совершенство, трагедия деградации, пути охраны и возрождения. Кишинев: Pontos, 2008. 285 с.

15. Лапа В. В., Цибулько Н. Н. Проблемы повышения плодородия и защиты от деградации почв Беларуси. Агрохімія і ґрунтознавство (спецвипуск). 2018. Кн. 2. С. 74-82.

16. Лебідь М. Т. Економічні основи застосування добрив в сільському господарстві: автореф. дис. ... канд. екон. наук: 08.07.02. Харків, 1999. 18 с.

17. Максаков В. И. О методике оценки эффективности удобрений. Агрохимический вестник. 2010. №6. С. $15-19$.

18. Медведев В. В., Пліско І. В., Накісько С. Г., Тітенко Г. В. Деградація ґрунтів у світі, досвід ії попере- 
дження і подолання. Харків : Стильна типографія, 2018. $168 \mathrm{c}$.

19. Методика експертної оцінки економічної доцільності застосування добрив / за ред. О. В. Харченка. Суми : Універс. книга, 2003. 33 с.

20. Методика разработки нормативов окупности минеральных удобрений прибавкой урожая сельскохозяйственных культур. Москва : ВНИИА, 2009. 64 с.

21. Носко Б. С. Фосфор у ґрунтах і землеробстві України. Харків : ФОП «Бровін О. В.», 2017. 476 с.

22. Оцінка методичних підходів щодо екологічного обґрунтування застосування добрив під сільськогосподарські культури / за ред. О. В. Харченка, В. I. Прасола. Суми : Універс. книга, 2011. 48 с.

23. Пуховский А. В. К методике оценки окупаемости минеральных удобрений и мелиорантов. Агрохимический вестник. 2010. №1. С. 35-40.

24. Справочник по определению норм удобрений под планируемый урожай / под ред. Ф. Е. Мосиюка и др. Киев : Урожай, 1989. 512 с.

25. Стаціонарні польові досліди України. Київ : Аграрна наука, 2014. 146 с.

26. Тараріко Ю. О. Енергозберігаючі агроекосистеми. Оцінка та раціональне використання агроресурсного потенціалу України (Рекомендації на прикладі Степу і Лісостепу). Київ: Діа, 2011. 576 с.

27. Технологічні карти та витрати на вирощування сільськогосподарських культур з різним ресурсним забезпеченням / за ред. Д. І. Мазоренка, Г. Є. Мазнєва. Харків : ХНТУСГ, 2006. 725 с.

28. Харченко О. В. Прасол В. I., Захарченко Е. А., Петренко Ю. М., Собко М. Г. До проблеми аналітичної оцінки ефективності мінеральних добрив та екологічних обмежень їх норми. Суми: Університетська книга, 2016. $32 \mathrm{c}$.

29. Ходаківська О. В. Корчинська С. Г., Матвієнко А. П. Еколого-економічні аспекти відтворення родючості ґрунтів. Землеробство. 2017. №1. С. 16-22.

30. Цвей Я. П., Бондар С. О., Семчук С. М. Формування родючості чорнозему в сівозмінах Лісостепу. Матер. Міжнар. н.-практ. конф. 7-8 червня 2018 р. «Інноваційні технології у рослинництві: проблеми та їх вирішення». Житомир: Рута, 2018. С. 267-271.

31. Marschner's Mineral Nutrition of Higher Plants. 3rd edition. Edited by P. Marschner. Amsterdam, Netherlands: Elsevier/Academic Press, 2012. 684 p.

\section{References}

1. Volkohon, V. V., Berdnikov, O. M., Lopushniak, V. I. (2019). Ecological aspects of the system of fertilization of agricultural crops. Kyiiv: Agrarian Science, 2019. 264 p. (in Ukrainian)

2. Hospodarenko, H. M. (2020). Practical course on Agrochemistry. Kyiiv : «SIK Group Ukraine», 2020. 148 p. (in Ukrainian)

3. Hospodarenko, H. M., Martyniuk, A. T., Boiko, V. P. (2021). Phosphorous balance in soil and efficiency of phosphorous deficiency of the fertilization system. Messenger of Uman NUH, 2021, no. 1, pp. 21-26. (in Ukrainian)

4. Hospodarenko, H. M., Cherno, O. D., Sukhomud, O. H. (1998). The issue of optimal content of mobile phosphorous and potassium forms in graded chernozem for crops of field rotation. Factors of soil fertility and their efficiency, Uman, 1998, pp. 66-71. (in Ukrainian)

5. Hospodarenko, S. H. (2004). Economic efficiency of the mineral system of fertilization in the field rotation. "Materials from the conference of young scientists". Uman, 2004, pp. 39-40. (in Ukrainian)

6. Hospodarenko, H. M. (2001). The development and grounding of integrated system of fertilization in field rotation in graded chernozem of the right-bank foreststeppe of Ukraine. Dr. agri. sci. diss. Kyiiv, 2001. 40 p. (in Ukrainian)

7. Dehodiuk, E.H., Derevianko, R.H., Lisovui, M.V. (1987). Methods of calculation of fertilizers norms for the planned yield. Handbook on fertilization of agricultural crops. Kyiiv : Yield, 1987, pp. 177-187. (in Ukrainian)

8. Miroshnychenko, M.M. (2011). Fertilizers: handbook. Kharkiv: V. V. Dokuchaiev KNAU, 2011. 224 p. (in Ukrainian)

9. Dotsenko, O. V. (2013). The influence of long-term usage of fertilizers on agrochemical indices of chornozem and the efficiency of resource saving systems of fertilization. Author. of dis. to obtain the degree of Ph.D. Kharkiv, 2013. 23 p. (in Ukrainian)

10. Fedorov, M.M., Mesel-Veseliak, V.Ya., Baliuk, S.A. et al. (2017). Evolution of methodological and methodical aspects of land evaluation in Ukraine. Kyiiv: NSC «IAE», 2017. 84 p. (in Ukrainian)

11. Kalinchyk, M. V., Ilchuk, M. M., Kalinchyk, M. B. (2006). Economical grounding of standards of applying mineral fertilizers according to the price on resources and production. Kyiiv : Nichlava, 2006. 43 p. (in Ukrainian)

12. Baliuk, S.A., Medvedev, V.V., Miroshnychenko, M.M. (2018). The concept of achieving of neutral level of soil degradation in Ukraine. Kharkiv: PIF Brovin O. V., 2018. 32 p. (in Ukrainian)

13. Kramariov, S. M., Kramariov, O. S. (2018). The content change of mobile forms of phosphorous in regular chernozem on the tillage in comparison with new soil and financial mechanism of its improvement. Agrarian chemistry and Soil Study (special edition), 2018, ed. 2, pp. 173-174. (in Ukrainian)

14. Krupenikov, I. A. (2008). Chernozems. Appearances, brilliance, tragedy of degradation, ways of protection and rennovation. Kyshyniov: Pontos, 2008. 285 p. (in Russian)

15. Lapa, V. V., Tsybulko, N. N. (2018). Problems of yield improvement and protection of degradation of soil in Belorussia. Agrarian Chemistry and Soil Study (special edition), 2018, ed. 2, pp. 74-82. (in Russian)

16. Lebid, M. T. (1999). Economical basis of the usage of fertilizers in agriculture. Author. of dis. to obtain the degree of Ph.D. Kharkiv, 1999. 18 p. (in Ukrainian)

17. Maksakov, V. I. (2010). On the methodics of evaluation of fertilizers efficiency. Agrarian and chemical messenger, 2010, no.6, pp. 15-19.(in Russian)

18. Medvedev, V.V., Plisko, I.V., Nakisko, S. H., Titenko, V.H. (2018). Soil degradation in the world, experience of its caution and covering. Kharkiv : Modern typography, 2018. 168 p. (in Ukrainian)

19. Kharchenko, O.V. (2003). Methodics of expert evaluation of economic effectiveness of using fertilizers. Sumy : University book, 2003. 33 p. (in Ukrainian)

20. Methodics of the development of standards of viability of mineral fertilizers with the help of yield increase of agricultural crops. Moscow : VNIIA, 2009. 64 p. (in Russian)

21. Nosko, B.S. (2017). Phosphor in soils and farming in Ukraine. Kharkiv : PIF «Brovin, O.V.», 2017. 476 p. (in Ukrainian)

22. Kharchenko, O.V., Prasol, V.I. (2011). Evaluation of methodological approaches to ecological grounding of using fertilizers for agricultural crops. Sumy : University book, 2011. 48 p. (in Ukrainian)

23. Pukhovskyi, A.V. (2010). On the methodics of evaluation of viability of mineral fertilizers and meliorants. Agrarian and chemical messenger, 2010, no.1,pp. 35-40. (in Russian)

24. Mosiiuk, F.Ye. (1989). Handbook on determining the standards of fertilization for planned harvest. Kiiev : Yield, 1989. 512 p. (in Russian)

25. Stationary field experiments of Ukraine. Kyiiv Agrarian Science, 2014. 146 p.(in Ukrainian)

26. Tarariko, Yu. O. (2011). Energy saving agrarian ecosystems. Evaluation and rational usage of agrarian resource potential of Ukraine (Recommendations on the basis of Steppe and Forest Steppe). Kyiiv: Dia, 2011. 576 p. (in Ukrainian)

27. Mazorenko, D.I., Mazniev, H.Ye. (2006). Technological cards and expenses on growing agricultural crops with different resource supply. Kharkiv : KhNTUA, 
2006. 725 p.(in Ukrainian)

28. Kharchenko, O. V., Prasol, V.I., Zakharchenko, E. A., Petrenko, Yu. M., Sobko, M. H. (2016). The issue of analytical evaluation of effectiveness of mineral fertilizers and ecological restrictions of their norms. Sumy: University book, 2016. 32 p. (in Ukrainian)

29. Khodakivska, O. V., Korchynska, S. H., Matviienko, A. P. (2017). Ecological and economical aspects of renovation of soil fertility. Agriculture. 2017,no. 1, pp. 1622. (inUkrainian)

30. Tsvei, Ya. P., Bondar, S. O., Semchuk, S. M. (2018). The formation of chernozem fertility during the rotation in Forest Steppe. Матер. International scientific practical conference on the 7-8 of June, 2018. «Innovative technologies in growing crops: problems and their solving». Zhytomyr: Ruta, 2018, pp. 267-271. (in Ukrainian)

31. Marschner's Mineral Nutrition of Higher Plants. 3rd edition. Edited by P. Marschner. Amsterdam, Netherlands: Elsevier/Academic Press, 2012. 684 p. 